\title{
HARPER'S WORLD
}

The Politicization of Canadian Foreign Policy, 2006-2015

Edited by Peter McKenna

In examining the nuts and bolts of former prime minister Stephen Harper's foreign policy universe between 2006 and 2015, Harper's World turns to key foreign policy experts to break down and evaluate Harper's international policies - from relations with China to his engagement with Canada's Arctic region. In explaining both the what and the why of Harper's foreign policy record, this book argues that the policy decisions of Harper's Conservative government were primarily shaped and motivated by domestic, regional, and, most importantly, electoral calculations.

Bringing together Canada's leading foreign policy specialists, Harper's World identifies the push and pull factors of Harper's approach to various Canadian foreign policy issues. This collection offers original analyses, factual evidence, case studies, and supporting documentation to shed light on Harper's foreign policy orientation during his almost ten years in power.

PETER McKENNA is a professor of political science at the University of Prince Edward Island. 
This page intentionally left blank 


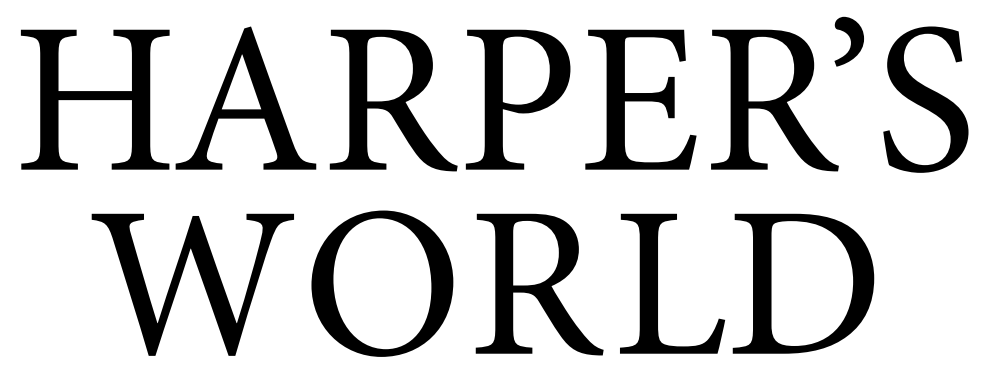

The Politicization of Canadian

Foreign Policy, 2006-2015

EDITED BY PETER McKENNA

UNIVERSITY OF TORONTO PRESS

Toronto Buffalo London 
Toronto Buffalo London

utorontopress.com

Printed in the U.S.A.

ISBN 978-1-4875-0210-2 (cloth)

ISBN 978-1-4875-1459-4 (EPUB)

ISBN 978-1-4875-2178-3 (paper)

ISBN 978-1-4875-1458-7 (PDF)

\section{Library and Archives Canada Cataloguing in Publication}

Title: Harper's world : the politicization of Canadian foreign policy, 2006-2015 / edited by Peter McKenna.

Names: McKenna, Peter, 1961- editor.

Description: Includes bibliographical references and index.

Identifiers: Canadiana (print) 20210369019 | Canadiana (ebook) 2021036906X | ISBN 9781487502102 (cloth) | ISBN 9781487521783 (paper) |

ISBN 9781487514594 (EPUB) | ISBN 9781487514587 (PDF)

Subjects: LCSH: Harper, Stephen, 1959- | CSH: Canada - Foreign relations -

21st century. | CSH: Canada - Politics and government - 2006-2015.

Classification: LCC FC650.H38 2022 | DDC 971.07/3 - dc23

This book has been published with the help of a grant from the Federation for the Humanities and Social Sciences, through the Awards to Scholarly Publications Program, using funds provided by the Social Sciences and Humanities Research Council of Canada.

We wish to acknowledge the land on which the University of Toronto Press operates. This land is the traditional territory of the Wendat, the Anishnaabeg, the Haudenosaunee, the Métis, and the Mississaugas of the Credit First Nation.

University of Toronto Press acknowledges the financial support of the Government of Canada and the Ontario Arts Council, an agency of the Government of Ontario, for its publishing activities.

Canada Council for the Arts
Conseil des Arts du Canada 
For Mom 
This page intentionally left blank 